Keywords:

Salt Waste Processing Facility Actinide Removal Project

Permanganate Removal of Actinides

Retention: $\quad$ Permanent

\title{
Permanganate Treatment of Savannah River Site Simulant Wastes for Strontium and Actinide Removal
}

\author{
W. R. Wilmarth \\ J. T. Mills \\ V. H. Dukes \\ F. F. Fondeur \\ D. T. Hobbs \\ M. C. Duff \\ S. D. Fink
}

May 22, 2003

\section{Westinghouse}

Savannah River Company

Aiken, SC 29808

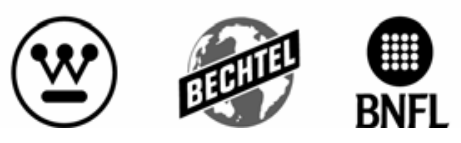


This document was prepared in conjunction with work accomplished under Contract No. DE-AC09-96SR18500 with the U. S. Department of Energy.

\section{DISCLAIMER}

This report was prepared as an account of work sponsored by an agency of the United States Government. Neither the United States Government nor any agency thereof, nor any of their employees, makes any warranty, express or implied, or assumes any legal liability or responsibility for the accuracy, completeness, or usefulness of any information, apparatus, product or process disclosed, or represents that its use would not infringe privately owned rights. Reference herein to any specific commercial product, process or service by trade name, trademark, manufacturer, or otherwise does not necessarily constitute or imply its endorsement, recommendation, or favoring by the United States Government or any agency thereof. The views and opinions of authors expressed herein do not necessarily state or reflect those of the United States Government or any agency thereof.

This report has been reproduced directly from the best available copy.

Available for sale to the public, in paper, from: U.S. Department of Commerce, National Technical Information Service, 5285 Port Royal Road, Springfield, VA 22161, phone: (800) 553-6847, fax: (703) 605-6900

email: orders@ntis.fedworld.gov

online ordering: http://www.ntis.gov/help/index.asp

Available electronically at http://www.osti.gov/bridge

Available for a processing fee to U.S. Department of Energy and its contractors, in paper, from: U.S. Department of Energy, Office of Scientific and Technical Information, P.O. Box 62, Oak Ridge, TN 37831-0062,

phone: (865)576-8401,

fax: (865)576-5728

email: $\underline{\text { reports@ adonis.osti.gov }}$ 


\section{ACRONYMS AND ABBREVIATIONS}

$\begin{array}{ll}\mathrm{HLW} & \text { High Level Waste } \\ \mathrm{HS} & \left.\text { Heat Source (i.e., mostly }{ }^{238} \mathrm{Pu}\right) \\ \mathrm{H}_{2} \mathrm{O}_{2} & \text { Hydrogen Peroxide } \\ \mathrm{ICP}-\mathrm{MS} & \text { Inductively-Coupled Plasma Mass Spectrometry } \\ \mathrm{M} & \text { Moles per Liter } \\ \mathrm{Mn} & \text { Manganese } \\ \mathrm{MnO}_{4}^{-} & \text {Permanganate Ion } \\ \mathrm{MST}_{\mathrm{Na}} & \text { Monosodium Titanate } \\ \mathrm{Na} & \text { Sodium } \\ \mathrm{Np} & \text { Sodium Birnessite } \\ \mathrm{Pu} & \text { Neptunium } \\ \mathrm{Sr} & \text { Plutonium } \\ \mathrm{SrCO} & \text { Strontium } \\ \mathrm{SRS} & \text { Strontium carbonate } \\ \mathrm{SRTC} & \text { Savannah River Site } \\ \text { WAC } & \text { Savannah River Technology Center } \\ \text { WG } & \text { Waste Acceptance Criterion } \\ \text { WPTS } & \left.\text { Weapons Grade (i.e., mostly }{ }^{239} \mathrm{Pu}\right) \\ \text { WSRC } & \text { Waste Processing Technology Section } \\ \text { ARP } & \text { Westinghouse Savannah River Company } \\ \text { SWPF } & \text { Alpha Removal Program } \\ \text { TTA } & \text { Salt Waste Processing Facility } \\ \text { DFs } & \text { ThenoylTrifluoroAcetone } \\ \text { TRU } & \text { Decontamination Factors }\end{array}$


Page 4 of 25

Table of Contents

ACRONYMS AND ABBREVIATIONS …

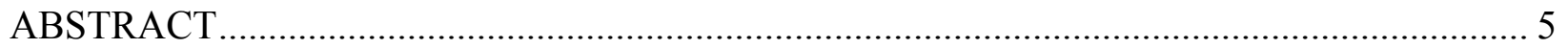

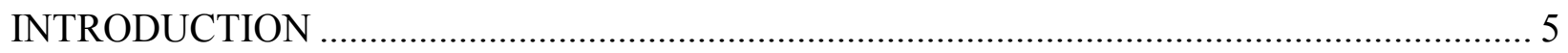

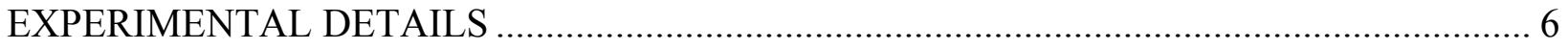

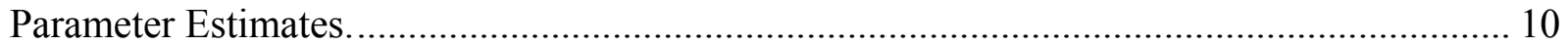

In-Tank Application Permanganate Treatment Process .......................................... 16

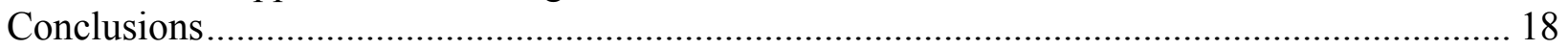

Permanganate Treatment using Simulated 5.6 M Sodium Waste....................................... 19

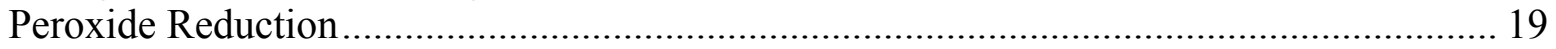

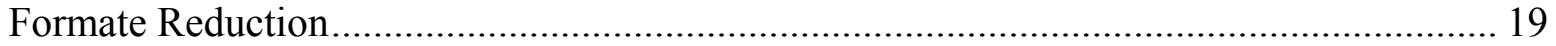

In-Tank Permanganate Treatment (7 M Sodium Waste) ................................................ 19

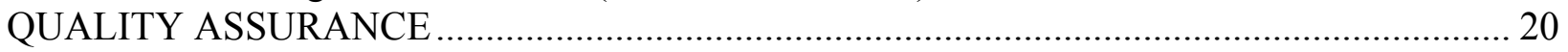

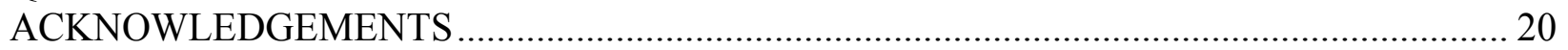

List of Tables

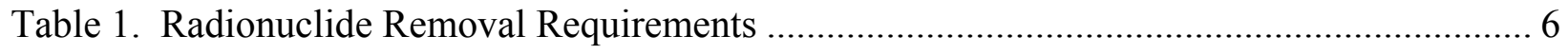

Table 2. Test Matrix for ARP-related Sr/TRU Removal ............................................... 7

Table 3. In-Tank Deployment Test Matrix ............................................................................. 8

Table 4. Plutonium Model for Peroxide Reduction using Simulated 5.6 M Sodium Waste....... 10

Table 5. Sr Model for Peroxide Reduction using Simulated 5.6 M Sodium Waste ................... 12

Table 6. Pu Model for Formate Reduction using Simulated 5.6 M Sodium Waste ................... 14

Table 7. Sr Model for Formate Reduction using Simulated 5.6 M Sodium Waste .................... 16

Table 8. Pu Model for In-Tank Permanganate Treatment (7.5 M Sodium Waste) .................... 17

Table 9. Sr Model for In-Tank Permanganate Treatment (7.5 M Sodium Waste) ..................... 18

Table 10. Decontamination Comparisons for ARP and In-Tank Applications ......................... 19

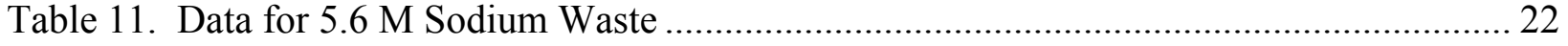

Table 12. Data for 7.5 M Sodium Waste (Formate as Reductant)........................................ 23

\section{List of Figures}

Figure 1. Plutonium Model for Peroxide Reduction using Simulated 5.6 M Sodium Waste..... 10

Figure 2. Effect of Strontium on the Reduction of Permanganate........................................... 11

Figure 3. Sr Model for Peroxide Reduction using Simulated 5.6 M Sodium Waste .................. 12

Figure 4. Pu Model for Formate Reduction using Simulated 5.6 M Sodium Waste .................. 13

Figure 5. Sr Model for Formate Reduction using Simulated 5.6 M Sodium Waste................... 15

Figure 6. Pu Model for In-Tank Permanganate Treatment (7.5 M Sodium Waste) ................... 17

Figure 7. Sr Model for In-Tank Permanganate Treatment (7.5 M Sodium Waste) .................... 18 


\title{
Permanganate Treatment of Savannah River Site Simulant Wastes for Strontium and Actinide Removal
}

\author{
W. R. Wilmarth, J. T. Mills, V. H. Dukes, F. F. Fondeur and S. D. Fink \\ Waste Processing Technology Section \\ Savannah River Technology Center
}

\begin{abstract}
This study examined the use of sodium permanganate and strontium nitrate to remove the actinides and radio-strontium from Savannah River Site (SRS) waste supernate. We examined the quantities of chemical feed reagents along with increased mixing and the excess of organic reductant. Additionally, we examined two processing schemes including that applicable to either the Salt Waste Processing Facility or the Alpha Removal Process (ARP) (5.6 M sodium ion concentration) conditions and the conditions for an In-Tank application (7.5 M sodium ion concentration). Our results support the following conclusions:
\end{abstract}

- The process met minimum required decontamination factors (DFs) within the tested parameter sets for strontium and plutonium in both the ARP and In-Tank application. The strontium DFs far exceeded the required values within the tested parameter sets.

- Within the ARP application, the use of peroxide as the reductant for permanganate produced higher plutonium DFs than the use of sodium formate.

- Reductant concentration and degree of mixing strongly influenced radionuclide decontamination. In the formate application under the ARP process, increasing the reductant concentration and mixing energy resulted in higher $\mathrm{Sr}$ and $\mathrm{Pu}$ decontamination.

\section{INTRODUCTION}

Project personnel identified the slow kinetics of actinide removal by treatment of Savannah River high-level waste using monosodium titanate as a technology risk for implementation in the Salt Waste Processing Facility. ${ }^{1}$ Table 1 provides processing requirements for the removal of radiostrontium and the transuranic (TRU) elements that emit alpha activity. Since spike simulants are being used in this testing, decontamination factors (DF) of 5 and 12 are required for strontium and the transuranic actinides, respectively, at initial concentrations of $100 \mu \mathrm{g} / \mathrm{L} \mathrm{Sr}$, $200 \mu \mathrm{g} / \mathrm{L}{ }^{239} \mathrm{Pu}, 10 \mathrm{mg} / \mathrm{L} \mathrm{U}$ and $400 \mu \mathrm{g} / \mathrm{L}^{2379} \mathrm{~Np}^{2}$ Studies in support of strontium and transuranic (Sr/TRU) removal for the Hanford wastes showed that an isotopic dilution with natural strontium and permanganate reduction proved effective at removing the $\mathrm{Sr} / \mathrm{TRU}$ constituents and could potentially produce the required decontamination in SRS wastes. ${ }^{3}$ 


\section{Table 1. Radionuclide Removal Requirements}

\begin{tabular}{|c|c|}
\hline Radionuclide & Requirement \\
\hline${ }^{90} \mathrm{Sr}$ & $<40 \mathrm{nCi} / \mathrm{g}$ \\
\hline Total alpha & $<18 \mathrm{nCi} / \mathrm{g}$ \\
\hline $\mathrm{Np}$ & $<0.03 \mathrm{nCi} / \mathrm{g}$ \\
\hline
\end{tabular}

Work performed by Barnes, ${ }^{4}$ et al., and Duff, ${ }^{5}$ et al., with Savannah River actual waste samples and simulants showed the permanganate treatment removed the strontium and transuranic constituents but decontamination was not as efficient in actual waste testing. Also, tests did not give highly reproducible results. Results showed that formate or peroxide effectively reduced the permanganate. Reaction of the formate occurred slowly at low concentration $(0.01 \mathrm{M})$, requiring as long as 24 hours to complete. Studies by Krot et al. (1998) indicate that the reduction of permanganate by peroxide to $\mathrm{Mn}(\mathrm{IV})$ oxide is nearly instantaneous whereas the reduction of permanganate by formate is slower due because the Mn(VII) is slowly converted by formate to $\mathrm{Mn}(\mathrm{IV})$ via single electron reduction steps. ${ }^{6}$ We believe we may overcome this slow oxidation of formate by either increasing the formate concentration or elevating the temperature. Hence personnel developed an alternate recipe using higher reagent concentrations. ${ }^{7}$ and successfully demonstrated the process with actual waste. ${ }^{8}$

While conducting similar experiments in support of the development of a Sr/TRU decontamination process for the Hanford Waste Treatment Plant, SRS researchers observed rapid kinetics with minimal reagent additions. ${ }^{3,8}$ Therefore, personnel completed a series of tests to further explore the permanganate reduction process for $\mathrm{Sr}$ /TRU decontamination of SRS wastes. The primary parameters of that work included strontium and permanganate levels, concentration of organic reductant, and degree of mixing. The tests used organic concentrations levels based on a stoichiometric amount (1X) being equivalent to 1.5 times the permanganate concentration in molar units. The testing showed that good mixing is vital to promote a rapid interaction between the organic reductant and the permanganate ion. Secondly, a high reductant concentration provides for rapid permanganate reduction facilitating actinide removal.

\section{EXPERIMENTAL DETAILS}

The research program aims at identifying conditions where the reduction of permanganate is relatively quick with the minimal amount of reductant used while minimizing the amount of manganese sent for vitrification. Testing examined two deployment strategies. The first used the permanganate flowsheet at conditions applicable to the Salt Waste Processing Facility or the Actinide Removal Process in 512-S facility. This deployment adds the reductant and the permanganate to waste containing $\sim 5.6 \mathrm{M}$ sodium ion. The second deployment, applicable for an in-tank strategy, assumes a sodium ion concentration in excess of $7 \mathrm{M}$. Deploying a permanganate treatment in the large source tanks for waste containing relatively low soluble actinides and strontium could allow for the direct disposal of waste through the Saltstone Production Facility. This would avoid the need to process the material through the Actinide 
Removal Process in Building 512-S. Similarly, such a first treatment on waste containing high concentrations of actinides could reduce the processing burden for monosodium titanate in either the Salt Waste Processing Facility or the Actinide Removal Process. Presumably, deployment in the large tanks would use either existing slurry pumps or Flygt mixers to mix the chemical feeds that will be added directly into the tank. Also, we omitted peroxide as a reagent for this deployment because of perceived safety- and corrosion-based concerns about the direct addition of a high volume of peroxide to carbon steel tanks.

For these tests, we prepared an SRS simulant using the recipe from prior studies. ${ }^{5}$ Technicians added radioactive tracer of ${ }^{85} \mathrm{Sr},{ }^{238} \mathrm{U},{ }^{237} \mathrm{~Np}$ and ${ }^{239} \mathrm{Pu}$ to the simulant. Appendix 1 contains the concentration of the reagents for making the stimulant. Personnel analyzed the solution to determine the concentration of analytes in the spiked simulant solutions. Initial analyses include only $\mathrm{Pu}$ and ${ }^{85} \mathrm{Sr}$ until we judged the solution reached equilibrium. Personnel then added peroxide after permanganate and strontium nitrate were well mixed in the solution. For the formate test, personnel added permanganate after sodium formate was well mixed in the solution.

Table 2 lists the tests scheduled for the $5.6 \mathrm{M}$ solution. Table 3 lists the tests for the In-Tank deployment with sodium ion concentrations of 7.5 M. For the In-Tank deployment tests, we used a syringe pump to deliver the permanganate solution at a scaled rate to the liquid surface containing the formate as the reductant. When using peroxide as the reductant, we added the permanganate solution to the waste simulant prior to the addition of the reductant. We added formate to the waste prior to treating with permanganate.

\section{Table 2. Test Matrix for ARP-related Sr/TRU Removal}

\begin{tabular}{|c|c|c|c|c|c|c|}
\hline \multirow{3}{*}{$\begin{array}{c}\text { Test No. } \\
1\end{array}$} & \multirow[b]{2}{*}{$\mathrm{Mn}(\mathrm{M})$} & \multirow[b]{2}{*}{ Reductant Choice } & \multicolumn{3}{|c|}{ Reductant } & \multirow[b]{2}{*}{ Temp $\left({ }^{\circ} \mathrm{C}\right)$} \\
\hline & & & Level & $\operatorname{Sr}(\mathrm{M})$ & Mixing & \\
\hline & 0.01 & Peroxide & $1 \mathrm{x}$ & 0 & Stir bar & 25 \\
\hline 2 & 0.01 & Peroxide & $1 \mathrm{x}$ & 0.005 & Stir bar & 25 \\
\hline 3 & 0.01 & Peroxide & $1 \mathrm{x}$ & 0.01 & Stir bar & 25 \\
\hline 4 & 0.01 & Peroxide & $3 x$ & 0 & Stir bar & 25 \\
\hline 5 & 0.01 & Peroxide & $3 x$ & 0.005 & Stir bar & 25 \\
\hline 6 & 0.01 & Peroxide & $3 x$ & 0.01 & Stir bar & 25 \\
\hline 7 & 0.03 & Peroxide & $1 x$ & 0 & Stir bar & 25 \\
\hline 8 & 0.03 & Peroxide & $1 x$ & 0.005 & Stir bar & 25 \\
\hline 9 & 0.03 & Peroxide & $1 x$ & 0.01 & Stir bar & 25 \\
\hline 10 & 0.03 & Peroxide & $3 x$ & 0 & Stir bar & 25 \\
\hline 11 & 0.03 & Peroxide & $3 x$ & 0.005 & Stir bar & 25 \\
\hline 12 & 0.03 & Peroxide & $3 x$ & 0.01 & Stir bar & 25 \\
\hline 13 & 0.03 & Formate & $1 x$ & 0 & Stir bar & 25 \\
\hline 14 & 0.03 & Formate & $1 x$ & 0 & orbital & 25 \\
\hline 15 & 0.03 & Formate & $1 x$ & 0.01 & Stir bar & 25 \\
\hline 16 & 0.03 & Formate & $3 x$ & 0 & Stir bar & 25 \\
\hline 17 & 0.03 & Formate & $3 x$ & 0 & orbital & 25 \\
\hline 18 & 0.01 & Formate & $3 x$ & 0.01 & Stir bar & 25 \\
\hline 19 & 0.01 & Formate & $3 x$ & 0.01 & orbital & 25 \\
\hline 20 & 0.03 & Formate & $1 x$ & 0 & Stir bar & 45 \\
\hline 21 & 0.03 & Formate & $1 x$ & 0.01 & Stir bar & 45 \\
\hline 22 & 0.03 & Formate & $3 x$ & 0 & Stir bar & 45 \\
\hline 23 & 0.01 & Formate & $3 x$ & 0.01 & Stir bar & 45 \\
\hline
\end{tabular}


Tests used $\sim 50 \mathrm{~mL}$ of simulant. Personnel collected samples after 4 hours and submitted for gamma analysis and plutonium- triphenyltrifluoroacetone (Pu-TTA) analysis. In performing the plutonium analyses, personnel performed a TTA separation. They spiked an aliquot of the sample with a ${ }^{238} \mathrm{Pu}$ tracer. All of the plutonium in the sample was reduced; an anion complexing agent (aluminum nitrate) was then added. The plutonium in the sample was then oxidized to a +4 oxidation state. The plutonium(IV) was then extracted from the matrix using a TTA solution. The TTA layer was mounted in a counting dish and analyzed by alpha spectroscopy. A blank sample was run with the batch of samples.

For the elevated temperature tests, we heated the salt solution to the designed temperature and added the appropriate reagents. After mixing at temperature for 4 hours, we cooled the mixtures to ambient laboratory temperature and filtered through $0.45 \mu \mathrm{m}$ nylon membrane filter.

We used the calculated decontamination factors (DFs) along with the variable parameter values from the tests in the JMP Statistical software package ${ }^{9}$ (version 4.0.4) for model regression. We selected models using a centered polynomial function to ensure proper identification of statistically significant variables. After identifying these variables, we obtained coefficient estimates using a linear model. Because many tests included a large excess of organic reductant, we corrected the measured DF for the volume dilution.

\section{Table 3. In-Tank Deployment Test Matrix}

\begin{tabular}{|c|c|c|c|c|}
\hline \multicolumn{5}{|c|}{ Reductant } \\
\hline Test No. & $\mathrm{Mn}(\mathrm{M})$ & Level & $\operatorname{Sr}(\mathrm{M})$ & $\operatorname{Temp}^{\circ}(\mathrm{C})$ \\
\hline 1 & 0.01 & $3 X$ & 0 & 35 \\
\hline 2 & 0.01 & $3 X$ & 0 & 45 \\
\hline$\overline{3}$ & 0.03 & $5 X$ & 0.005 & 35 \\
\hline 4 & 0.03 & $5 X$ & 0.005 & 45 \\
\hline 5 & 0.01 & $5 X$ & 0.01 & 45 \\
\hline 6 & 0.01 & $5 X$ & 0 & 45 \\
\hline 7 & 0.03 & $3 X$ & 0.01 & 35 \\
\hline 8 & 0.03 & $3 X$ & 0.005 & 45 \\
\hline 9 & 0.03 & $1 X$ & 0.01 & 35 \\
\hline 10 & 0.03 & $1 X$ & 0.01 & 45 \\
\hline 11 & 0.01 & $1 \mathrm{X}$ & 0.005 & 35 \\
\hline
\end{tabular}

Reductant Level: $1 \mathrm{X}=$ Stochiometric and $3 \mathrm{X}=3$ times stoichiometric

\section{RESULTS AND DISCUSSION}

\section{Salt Waste Processing Facility and Actinide Removal Process: Peroxide Reductant}

The Salt Waste Processing Facility and the Actinide Removal Project assume a baseline of 5.6 M sodium ion concentration and use monosodium titanate as the Sr/TRU sorbent. This testing employed an addition of strontium nitrate followed by the reduction of sodium permanganate with one of two organic reducing agents: hydrogen peroxide or sodium formate. In the experiments with peroxide, we added the permanganate to the waste simulant prior to peroxide addition. This step minimized foaming during peroxide addition. Conversely, in the experiments 
with formate, we added the formate prior to the permanganate. This step made the stimulant resemble Hanford complexant waste.

Figure 1 shows the plutonium model developed from the data (Table 2) from the tests $(5.6 \mathrm{M}$ sodium ion concentration) using peroxide as the reductant. Appendix 1 contains the data measured during all of our experiments. The model has a correlation coefficient $\left(\mathrm{R}^{2}\right)$ of 0.68 and the data scatters randomly through the model range. Plutonium decontamination factors $(\mathrm{Pu}$ DFs) ranged from 1 (or no decontamination) to 95 after a 4 hour reaction time. The lowest value of $\mathrm{Pu} \mathrm{DF}$ occurred with the addition of $0.01 \mathrm{M}$ permanganate and $1 \mathrm{X}$ organic reductant. Conversely, the highest DF of 95 occurred with $0.03 \mathrm{M}$ permanganate and $3 \mathrm{X}$ organic reductant.

Table 4 contains the statistical analysis of the modeling effort. The statistically meaningful model takes the following form:.

$$
\mathrm{DF}_{\mathrm{Pu}}=79.8-3680 *[\mathrm{Mn}]-27.1 * \operatorname{Red} \text { Level }+1980 *[\mathrm{Mn}] * \text { Red Level }
$$

Two variables proved statistically significant at $95 \%$ confidence (i.e., a probability of the value exceeding the t-test, Prob. $>|\mathrm{t}|$, less than 0.05 ): the amount of sodium permanganate added to the system and a cross term of the molar level of sodium permanganate added and the reductant level. The model shows the strong positive effect of a coupled permanganate-reductant interaction. This cross term supports the theory that the decontamination needs a large excess of reductant to accelerate the reduction of permanganate.

Note that the plutonium removal does not (statistically) depend on the addition of strontium nitrate. Hence, the precipitation of strontium solids carries notable less plutonium - either by sorption or by coprecipitation - than the precipitating manganese solids. Inspection of the data revealed that the presence of $\mathrm{Sr}$ and not in excess amount is required for $\mathrm{Pu} \mathrm{DF}$. This onset effect of $\mathrm{Sr}$ on $\mathrm{Pu} \mathrm{DF}$ is not statistically detected since the effect is not dependent on $\mathrm{Sr}$ concentration. 


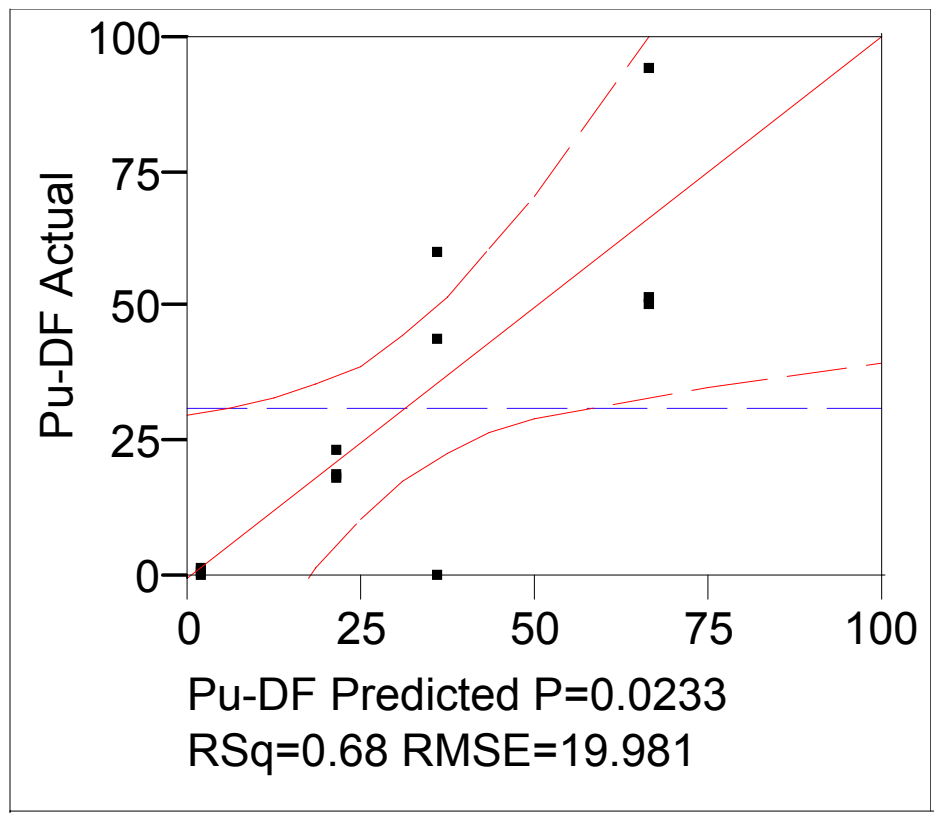

Figure 1. Plutonium Model for Peroxide Reduction using Simulated 5.6 M Sodium Waste

Table 4. Plutonium Model for Peroxide Reduction using Simulated 5.6 M Sodium Waste Parameter Estimates.

Term

Intercept

$\mathrm{NaMnO}_{4}$

Red Level

$\mathrm{NaMnO}_{4}{ }^{*}$ Red Level

$\begin{array}{rrrr}\text { Estimate } & \text { Std Error } & \text { t Ratio } & \text { Prob }>|t| \\ 79.8 & 28.8 & 2.77 & 0.0244 \\ -3680 & 1290 & -2.85 & 0.0214 \\ -27.1 & 12.9 & -2.10 & 0.0685 \\ 1980 & 580 & 3.43 & 0.0089\end{array}$




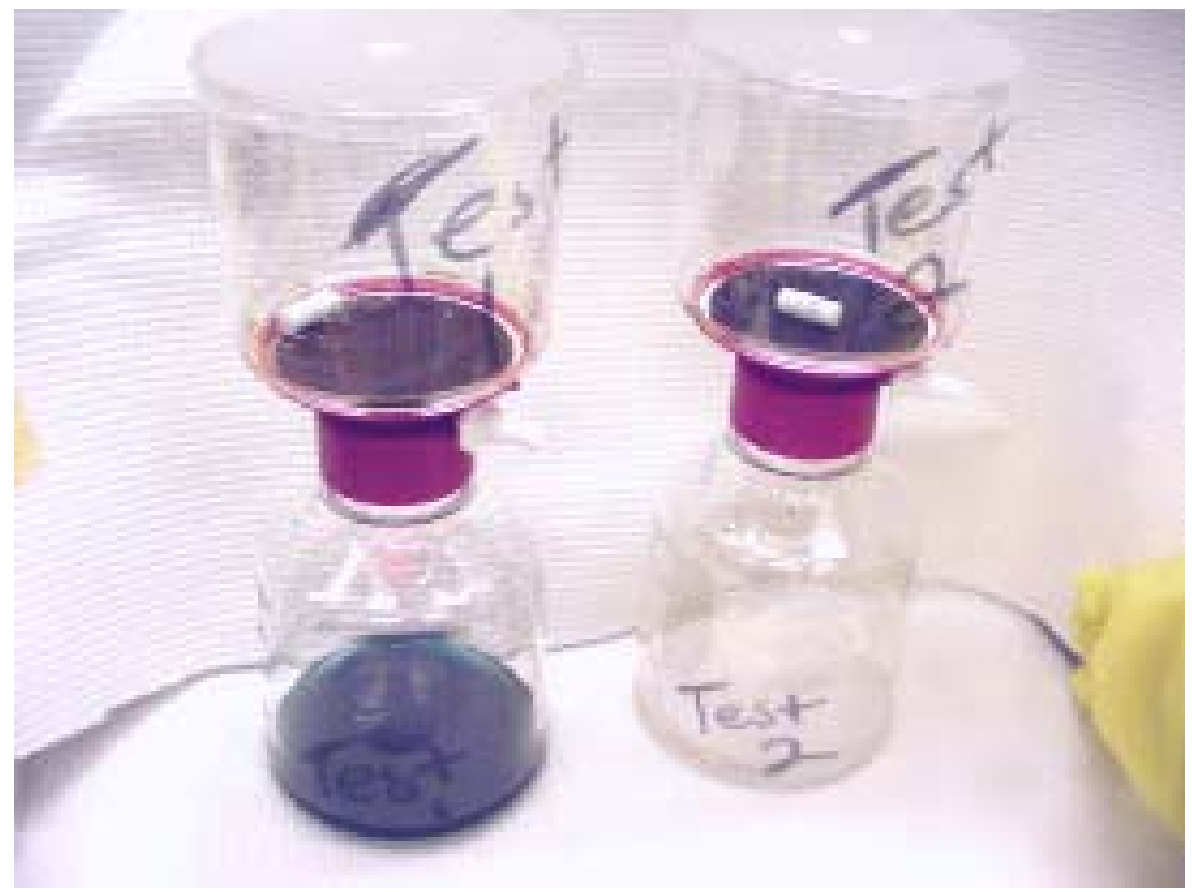

Figure 2. Effect of Strontium on the Reduction of Permanganate

The level of strontium added to the system was not statistically significant since the effect is due to the presence of $\mathrm{Sr}$ and it is not proportional to the amount of $\mathrm{Sr}$ in solution. Polynomials can not fit step changes in Pu DF behavior with Sr. However, experimental observations indicate that the presence of strontium precipitate was important as shown in Figure 2. These flasks contain solution from experiments numbered 1 and 2 . These tests included the addition of 0.01 $\mathrm{M}$ sodium permanganate to a $5.6 \mathrm{M}$ sodium salt solution followed by the addition of a $1 \mathrm{X}$ addition of peroxide as the reductant. In the test labeled number 1, we omitted the strontium nitrate and decontamination for plutonium did not occur $(\mathrm{Pu} \mathrm{DF}=1)$. However, in the test labeled number 2 (in Figure 2), we added $0.05 \mathrm{M}$ strontium nitrate prior to the addition of permanganate and peroxide obtaining a Pu DF of 61. It is clear from Figure 2 that in test number 1 the permanganate did undergo completely reduction as is evidenced by the blue color of $\mathrm{Mn}(\mathrm{V})$. We did not determine the length of time the solution retained its blue color.

Figure 3 shows the model for permanganate-peroxide decontamination of strontium using $5.6 \mathrm{M}$ sodium waste. The model more closely replicates the data and exhibits a correlation coefficient $\left(\mathrm{R}^{2}\right)$ of 0.89 . Under all conditions tested with sodium permanganate and peroxide in the $5.6 \mathrm{M}$ salt solution, strontium decontamination occurred rapidly and with high efficiency. The Sr DFs ranged from 39 to $\sim 4000$. Table 5 includes parameter estimates for the model. 


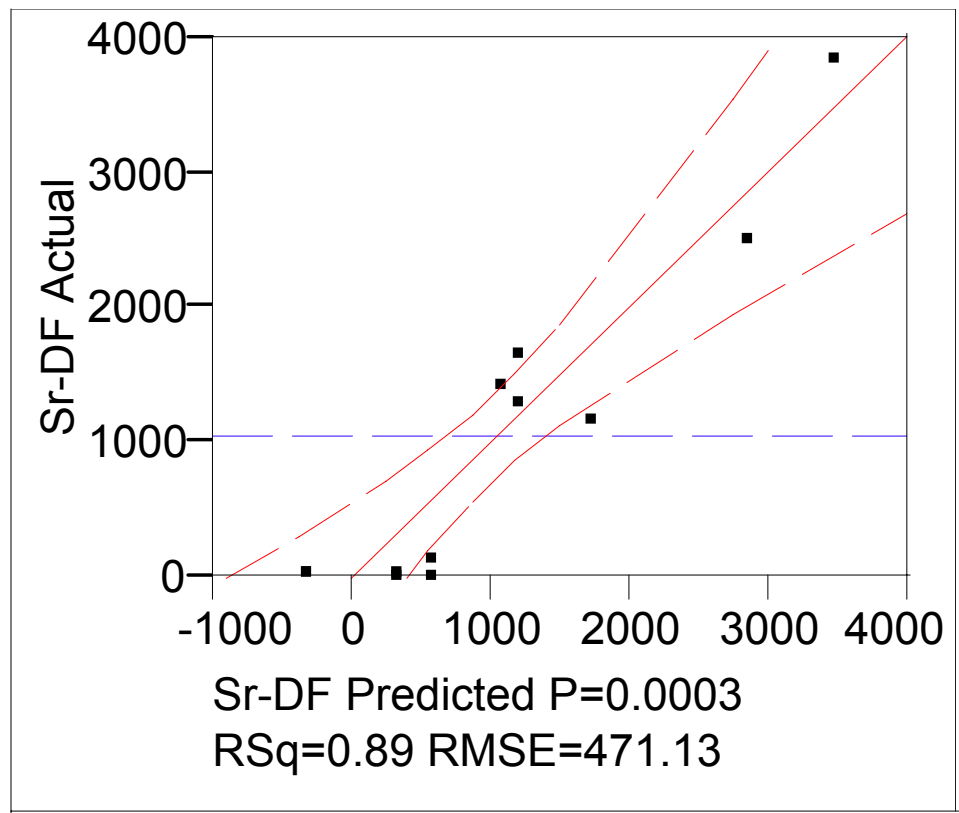

Figure 3. Sr Model for Peroxide Reduction using Simulated 5.6 M Sodium Waste

Table 5. Sr Model for Peroxide Reduction using Simulated 5.6 M Sodium Waste

Term

Intercept

$\mathrm{Sr}\left(\mathrm{NO}_{3}\right)_{2}$

Red Level

$\left(\mathrm{Sr}\left(\mathrm{NO}_{3}\right)_{2}-0.007\right) *\left(\mathrm{NaMnO}_{4}-0.02\right)$

$\begin{array}{rrrr}\text { Estimate } & \text { Std Error } & \text { t Ratio } & \text { Prob }>|t| \\ 2920 & 360 & 8.11 & <.0001 \\ -1.84 \mathrm{E} 5 & 2.89 \mathrm{E} 4 & -6.37 & 0.0002 \\ -323 & 136 & -2.38 & 0.0447 \\ 1.32 \mathrm{E} 7 & 2.89 \mathrm{E} 6 & 4.58 & 0.0018\end{array}$

Several factors in Table 5 are statistically significant including: the strontium nitrate concentration, the organic reductant concentration, and a cross term between the strontium and permanganate concentrations. The model's equation is shown below:

$\mathrm{DF}_{\mathrm{Sr}}=2920-1.84 \mathrm{E} 5 *\left[\mathrm{Sr}\left(\mathrm{NO}_{3}\right)_{2}\right]-323 *$ Red Level $+1.32 \mathrm{E} 7 *\left(\left[\mathrm{Sr}\left(\mathrm{NO}_{3}\right)_{2}\right]-0.007\right) *$ $\left(\left[\mathrm{NaMnO}_{4}\right]-0.02\right)$

Due to the large value of the intercept in this model, the strontium nitrate term and the reductant level have negative estimates. The cross term involving the strontium and permanganate does, however, strongly indicate that manganese is involved in the strontium decontamination. Wilmarth, et al., ${ }^{3}$ found a similar behavior for manganese in the strontium removal from Hanford's complexant concentrate waste. Hence, strontium removal appears to occur by two mechanisms: through isotopic dilution and precipitation effected by added strontium nitrate as well as by sorption or precipitation effected by reduction of the permanganate. 
Duff, et al., ${ }^{5}$ previously examined the use of sodium formate as the reductant and formate offers a reaction basis similar to the Hanford process since the organic reductant is dissolved in solution prior to addition of sodium permanganate solution. Therefore, we performed a series of experiments to examine the effects of reductant level, permanganate level, and temperature on decontamination of the feed (5.6 M sodium). We allowed the heated solutions to cool to room temperature before sampling. The cooling effect may have dissolved $\mathrm{SrCO}_{3}$ particles and released sorbed actinides. We can not quantify the impact of cooling on the resulting data. Thus, models which contain temperature terms are confounded with the effects resulting from allowing the test mixture to cool before sampling.

Note that 4 of the 11 experiments occurred at an elevated temperature (i.e., $45^{\circ} \mathrm{C}$ ) outside the current conceptual design for either the Actinide Removal Process or the Salt Waste Processing Facility. The reader may view these as intending to examine the ability to expand the capacity of the facilities without additional capital investment. Also, the reader is cautioned that the modeling effort is fundamentally shifted from the work on peroxide. By not including Temperature as a variable in the peroxide study, we implicitly assumed that the peroxide induced reduction of permanganate would occur extremely rapidly, would serve as the dominant mechanism for decontamination, and that heating would offer little value to speed the reaction. The modeling work for peroxide confirm these assumptions relative to plutonium but suggest that improved strontium performance may result had higher temperature been used (since strontium carbonate, a presumed precipitate from addition of strontium, shows retrograde solubility with temperature).

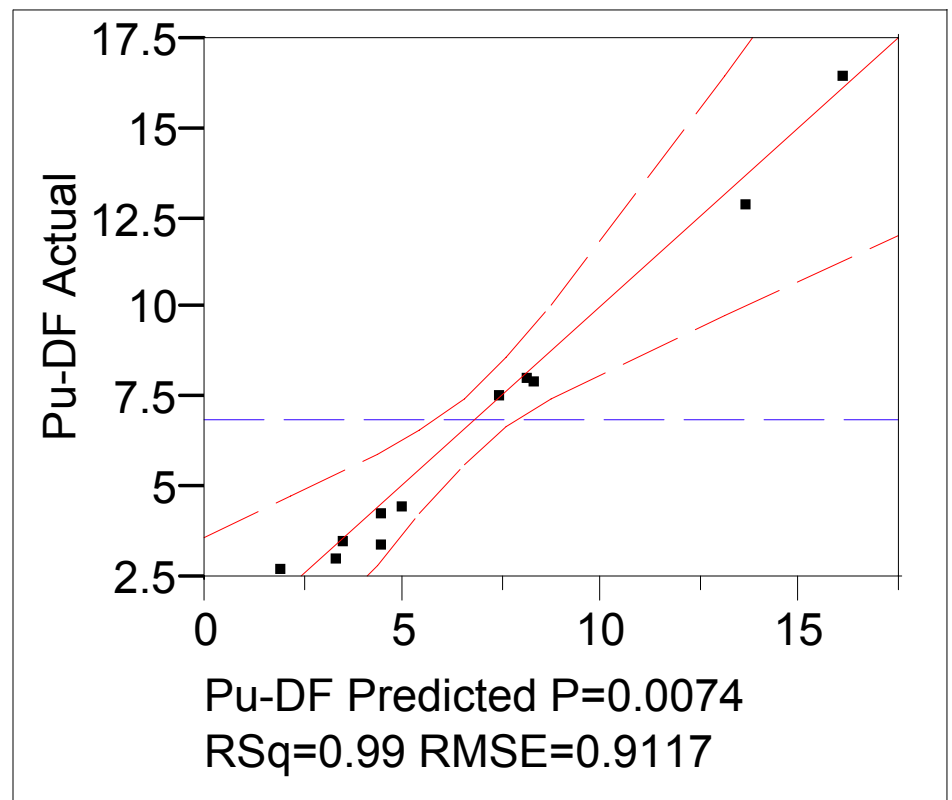

Figure 4. Pu Model for Formate Reduction using Simulated 5.6 M Sodium Waste 
Figure 4 shows the plutonium model for the formate reduction of permanganate using simulated waste containing $5.6 \mathrm{M}$ sodium. The plutonium decontamination factors ranged from 2.5 to above 16. These decontamination factors are significantly lower than those resulting from the peroxide reduction. However, observations indicated that reduction of the permanganate completed in the 4 hour reaction period (i.e., all filtrates after 4 hours appeared clear). The model generated from this data set had a correlation coefficient $\left(\mathrm{R}^{2}\right)$ of 0.99 .

Table 6 includes the model parameter estimates for the formate reduction tests. Four primary effects prove statistically significant including: the strontium concentration, the reductant concentration, mixing level, and temperature. Two other cross terms proved significant at the 95\% level: the term involving $\mathrm{Sr}$ and mixing as well as the term involving $\mathrm{Sr}$ and temperature. The primary variable of permanganate concentration is not significant for this data set, in strong contrast to the findings for peroxide. This indicates that at the levels tested $(0.01 \mathrm{M}$ and $0.03 \mathrm{M})$ insufficient variation in the response variable $(\mathrm{Pu} D F)$ exists. Hence, in these tests the strontium chemistry dominated the removal of plutonium, likely through a co-precipitation mechanism. Formate reduction proves much less effective in rapidly reducing permanaganate in a manner the effects plutonium removal. ${ }^{6}$ The statistically significant variables are included in the model equation as shown below:

$D F_{P u}=18.1-117.2 \times[S r]+0.49 \times[$ Reductant Level $]-0.41 \times[$ Temperature $]$

$-117.5 \times[\mathrm{Sr}-0.005] \times[$ Reductant Level - 2]

$+[\mathrm{Sr}-0.005] \times[273.5$ if no mixing or -273 if there is mixing]

$+34.2 \times[\mathrm{Sr}-0.005] \times[\mathrm{Temp}-33]+[-3.2$ if no mixing or 3.2 if

there is mixing]

\section{Table 6. Pu Model for Formate Reduction using Simulated 5.6 M Sodium Waste}

$\begin{array}{lrrrr}\text { Term } & \text { Estimate } & \text { Std Error } & \mathrm{t} \text { Ratio } & \text { Prob }>|\mathrm{t}| \\ \text { Intercept } & 22.6 & 1.61 & 14.05 & 0.0008 \\ \mathrm{Sr}\left(\mathrm{NO}_{3}\right)_{2} & -1005 & 245 & -4.10 & 0.0263 \\ \text { Red Level } & 1.23 & 0.372 & 3.31 & 0.0453 \\ \mathrm{Sr}\left(\mathrm{NO}_{3}\right)_{2}{ }^{*} \text { Red Level } & -133 & 58.8 & -2.27 & 0.1083 \\ \text { Mixing[0] } & -4.33 & 0.456 & -9.49 & 0.0025 \\ \mathrm{Sr}\left(\mathrm{NO}_{3}\right)_{2}{ }^{*} \text { Mixing[0] } & 250 & 75.6 & 3.31 & 0.0455 \\ \text { Temp } & -0.58 & 0.0456 & -12.78 & 0.0010 \\ \mathrm{Sr}\left(\mathrm{NO}_{3}\right)_{2}{ }^{*} \text { Temp } & 34.3 & 6.45 & 5.31 & 0.0130\end{array}$

Figure 5 shows the model for strontium decontamination using sodium formate as a reductant for sodium permanganate. The model shows a very strong bias to a single point with a very high measured decontamination factor. For this reason, we generated a second model without this 
point with Table 7 containing these parameter estimates. The equation for this model is shown below:

$$
\begin{aligned}
\mathrm{DF}_{\mathrm{Sr}}= & 8690-8.41 \mathrm{E} 5 *\left[\mathrm{Sr}\left(\mathrm{NO}_{3}\right)_{2}\right]+2.73 \mathrm{E} 4 *\left(\mathrm{Temp}-33{ }^{\circ} \mathrm{C}\right) *\left(\left[\mathrm{NaMnO}_{4}\right]-0.024\right) \\
& +310 *\left(\mathrm{Temp}-33^{\circ} \mathrm{C}\right) *(\text { Red Level }-2)
\end{aligned}
$$

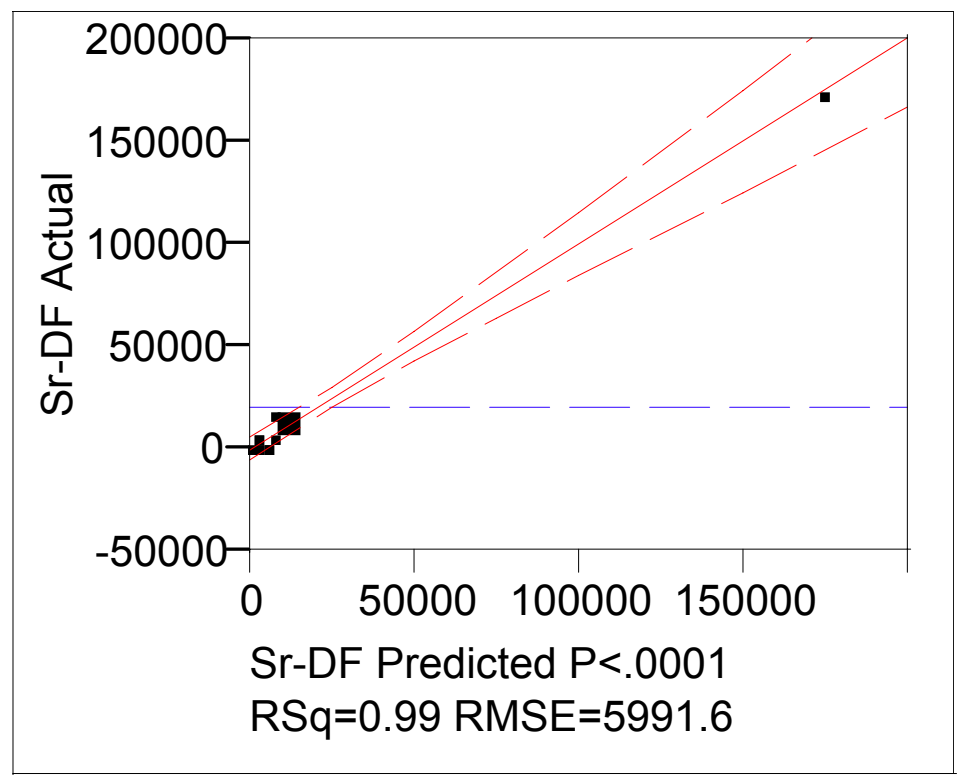

Figure 5. Sr Model for Formate Reduction using Simulated 5.6 M Sodium Waste

The new model of the decontamination of strontium from the $5.6 \mathrm{M}$ sodium feed using an addition of strontium nitrate and sodium formate to reduce sodium permanganate includes terms in the model. The first term is the amount of strontium nitrate. The strontium decontamination model for the formate reduction is very similar to the peroxide in that the magnitude of the $\mathrm{Sr}$ term is large and negative. This indicates that low levels of strontium are advantageous and that higher levels do not significantly assist in further decontamination. Two temperature cross terms appear in the model. The first involving the permanganate concentration and the second involving the reductant level. These two terms influence the amount of strontium removed via the manganese solids sorption or co-precipitation along with the temperature effect on the solubility of strontium carbonate. In general, both strontium models agree in the $5.6 \mathrm{M}$ sodium feed and indicate two mechanisms are occurring: isotopic dilution and manganese sorption/coprecipitation. 


\section{Table 7. Sr Model for Formate Reduction using Simulated 5.6 M Sodium Waste}

$\begin{array}{lrrrr}\text { Term } & \text { Estimate } & \text { Std Error } & \mathrm{t} \text { Ratio } & \text { Prob }>|\mathrm{t}| \\ \text { Intercept } & 8690 & 1075 & 8.08 & 0.0002 \\ \mathrm{Sr}\left(\mathrm{NO}_{3}\right)_{2} & -8.41 \mathrm{E} 5 & 1.52 \mathrm{E} 5 & -5.52 & 0.0015 \\ (\mathrm{Temp}-33)^{*}\left(\mathrm{NaMnO}_{4}-0.024\right) & 2.73 \mathrm{E} 4 & 1.10 \mathrm{E} 4 & 2.47 & 0.0482 \\ (\text { Temp-33)*(Redu-Level-2) } & 310 & 100 & 3.08 & 0.0217\end{array}$

\section{In-Tank Application Permanganate Treatment Process}

To examine the effectiveness at high sodium ion concentrations, we performed tests using a 7.5 $\mathrm{M}$ sodium salt solution, followed by the addition of sodium formate as a reductant, and finally sodium permanganate. We sampled the reaction system after four hours and analyzed for soluble strontium and plutonium. Table 3 contains the experimental design for these tests.

Figure 6 shows the plutonium model from the formate reduction of permanganate under In-Tank conditions (7.5 M sodium). The model replicates the data well over the response space and possesses a high correlation coefficient. The Pu DFs ranged from 1 to 9.2 at the $7.5 \mathrm{M}$ sodium level. Table 8 contains the parameter estimates. The plutonium decontamination model takes the form of the following:

$$
\begin{aligned}
\mathrm{DF}_{\mathrm{Pu}}= & 6.98+224 *\left[\mathrm{NaMnO}_{4}\right]-0.242 * \text { Red Level }-0.19 * \text { Temp } \\
& -25.4 *\left(\left[\mathrm{NaMnO}_{4}\right]-0.021\right) *(\mathrm{Temp}-40.5) \\
& +0.104 *(\text { Red Level }-3.2) *(\text { Temp }-40.5)
\end{aligned}
$$

Several terms influence the plutonium decontamination including the primary variables of permanganate, reductant level and temperature. The effect of permanganate addition is as expected with the higher level of addition leading to a higher decontamination. The amount of reductant does not appear to have much of effect differing from the experimental results at $5.6 \mathrm{M}$ sodium ion concentration. Temperature, also, is not a strong influence on the removal of plutonium. The other terms included in the model and are a cross term of permanganate and temperature and a cross term involving the reductant level and temperature. It appears that the higher ionic strength (starting less than $5.6 \mathrm{M}$ ) reduces the dependency on reductant and temperature to effect a rapid reduction of the permanganate ion. Possibly the stability of the permanganate is lower at 7.5 $\mathrm{M}$ sodium compared to $5.6 \mathrm{M}$ sodium ion. 


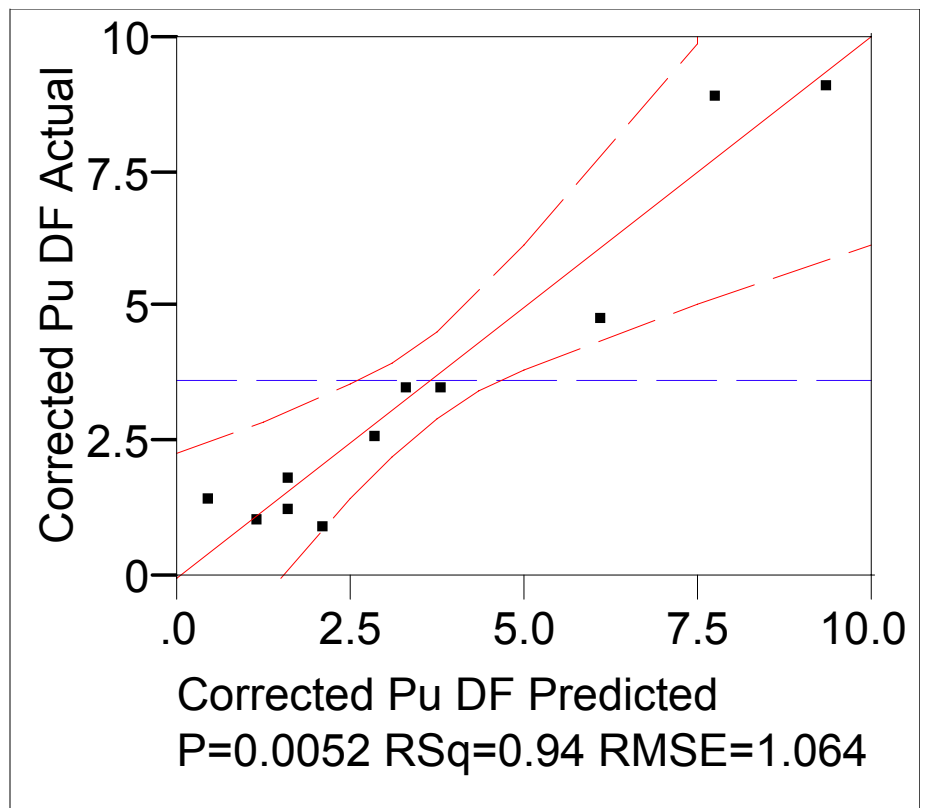

Figure 6. Pu Model for In-Tank Permanganate Treatment (7.5 M Sodium Waste)

Table 8. Pu Model for In-Tank Permanganate Treatment (7.5 M Sodium Waste)

Term

Intercept

$\mathrm{NaMnO}_{4}(\mathrm{M})$

Reductant Level

$\mathrm{Temp}(\mathrm{C})$

$\left(\mathrm{NaMnO}_{4}(\mathrm{M})-0.021\right) *(\mathrm{Temp}(\mathrm{C})-40.5)$

(Reductant Level-3.2)*(Temp(C)-40.5)

$\begin{array}{rrrr}\text { Estimate } & \text { Std Error } & \mathrm{t} \text { Ratio } & \text { Prob }>|\mathrm{t}| \\ 6.98 & 2.88 & 2.42 & 0.0599 \\ 224 & 35.3 & 6.35 & 0.0014 \\ -0.242 & 0.23 & -1.03 & 0.3492 \\ -0.190 & 0.070 & -2.73 & 0.0413 \\ -25.4 & 7.07 & -3.60 & 0.0156 \\ 0.104 & 0.047 & 2.22 & 0.0768\end{array}$

Figure 7 and Table 9 show the performance of the strontium model and estimated parameters. The model is somewhat limited since the data is weighted by a data point with a Sr DF $\sim 9000$. Note, however the model exhibits a high correlation coefficient. Three primary terms are statistically significant and are cross terms involving the four tested variables. The model's equation is shown below:

$$
\begin{aligned}
\mathrm{DF}_{\mathrm{Sr}}= & 507+7.15 \mathrm{E} 7 *\left(\left[\mathrm{NaMnO}_{4}\right]-0.012\right) *\left(\left[\mathrm{Sr}\left(\mathrm{NO}_{3}\right)_{2}\right]-0.0055\right) \\
& +2.02 \mathrm{E} 5 *(\operatorname{Red} \mathrm{Level}-3.18) *\left(\left[\mathrm{Sr}\left(\mathrm{NO}_{3}\right)_{2}\right]-0.0055\right) \\
& +7.82 \mathrm{E} 4 *\left(\left[\mathrm{Sr}\left(\mathrm{NO}_{3}\right)_{2}\right]-0.0055\right) *(\mathrm{Temp}-40.5)
\end{aligned}
$$




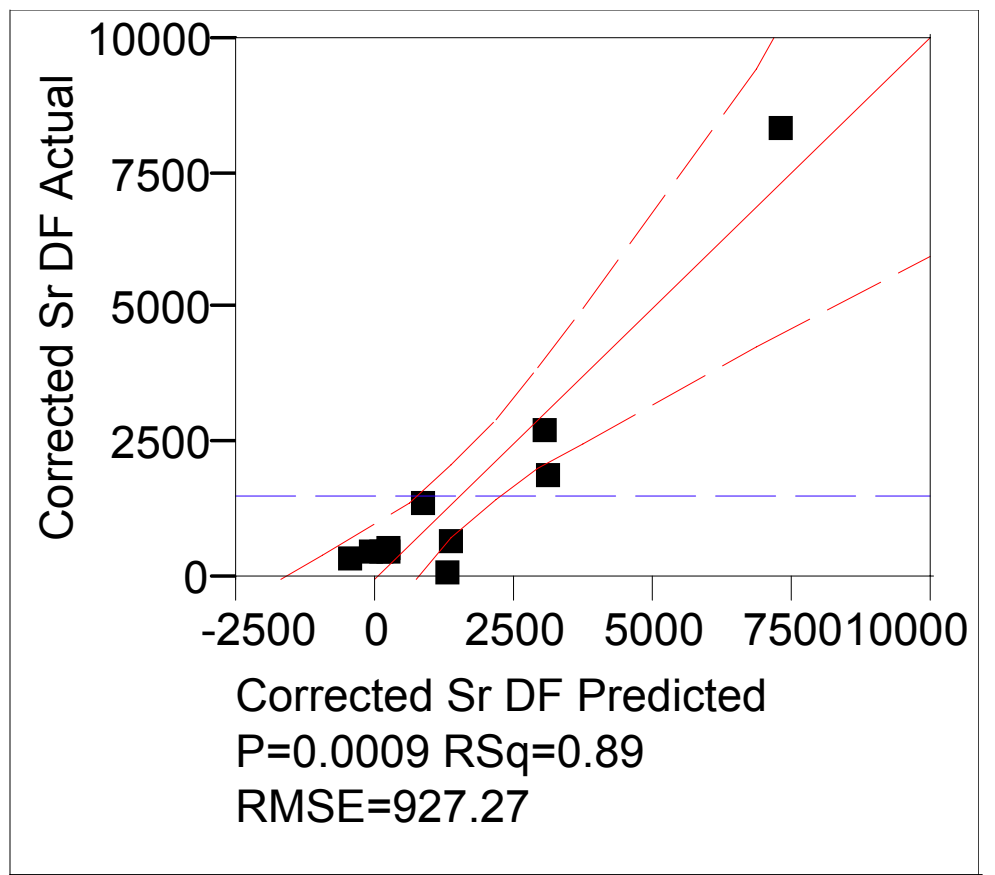

Figure 7. Sr Model for In-Tank Permanganate Treatment (7.5 M Sodium Waste)

\begin{tabular}{|c|c|c|c|c|}
\hline Term & Estimate & Std Error & t Ratio & Prob $>\mid t$ \\
\hline Intercept & 507 & 336 & 1.51 & 0.17 \\
\hline $\left.\mathrm{NaMnO}_{4}(\mathrm{M})-0.021\right)^{*}\left(\mathrm{Sr}\left(\mathrm{NO}_{3}\right)_{2}(\mathrm{M})-0.005\right.$ & 7.15E7 & $1.06 \mathrm{E} 7$ & 6.74 & 0.00 \\
\hline Red Level-3.18)*( $\left.\mathrm{Sr}\left(\mathrm{NO}_{3}\right)_{2}(\mathrm{M})-0.0055\right)$ & $2.02 \mathrm{E} 5$ & $6.59 \mathrm{E} 4$ & 3.07 & \\
\hline $\left.\mathrm{Sr}\left(\mathrm{NO}_{3}\right)_{2}(\mathrm{M})-0.0055\right) *(\mathrm{Temp}(\mathrm{C})-40.5)$ & $7.82 \mathrm{E} 4$ & $1.58 \mathrm{E} 4$ & 4.93 & 0.00 \\
\hline
\end{tabular}

Table 9. Sr Model for In-Tank Permanganate Treatment (7.5 M Sodium Waste)

The strontium decontamination model clearly indicates that removal is accomplished via two mechanisms. The first involves a simple isotopic dilution and strontium solubility and the second involves co-precipitation/sorption onto manganese oxide surfaces.

\section{CONCLUSIONS}

The models developed for the removal of strontium and plutonium from simulated waste solutions show that several of the tested variables influence radionuclide removal. The same level of each of the tested variables may not support simultaneous removal of strontium and plutonium. Likewise, due to the differences in ionic strength and chemical activity, the tested variables may influence the decontamination differently at higher sodium concentrations.

Therefore, Table 10 shows a compilation of the variables that influence strontium and plutonium removal for both the ARP, the SWPF, and In-Tank applications of the SRS Sr/TRU permanganate flowsheet. It is recognized that the models present in this report are generated from only a very few number of tests and that larger, more complete experimental designs could improve the model's predictive capability. However, the data presented in Table 10 does 
provide general insights the process chemistry. The optimal process and reagent levels were generated from maximizing models.

Table 10. Decontamination Comparisons for ARP and In-Tank Applications

Permanganate Treatment using Simulated 5.6 M Sodium Waste

Peroxide Reduction

$\begin{array}{llll} & \text { Sr Level } & \text { Mn Level } & \text { Reductant } \\ \text { Sr DF } & \text { Low } & \text { Low } & \text { Low } \\ \text { Pu DF } & & \text { High } & \text { High }\end{array}$

Formate Reduction

$\underline{\text { Sr Level }} \underline{\text { Mn Level }} \underline{\text { Reductant }} \underline{\text { Mixing }} \underline{\text { Temp }}$

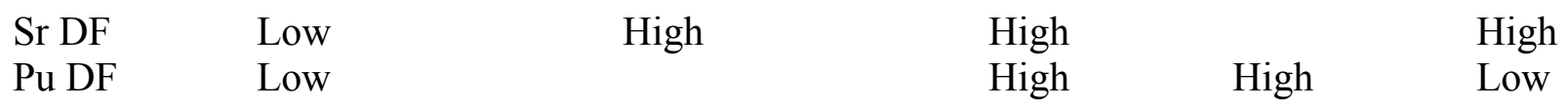

In-Tank Permanganate Treatment (7 M Sodium Waste)

\begin{tabular}{|c|c|c|c|c|}
\hline & $\underline{\text { Sr Level }}$ & $\underline{\text { Mn Level }}$ & $\underline{\text { Reductant }}$ & $\underline{\text { Temp }}$ \\
\hline Sr DF & Low & Low & & Low \\
\hline $\mathrm{Pu} \mathrm{DF}$ & & High & Low & Low \\
\hline
\end{tabular}

In the peroxide testing, three variables were examined (Strontium, Permanganate and Reductant levels). To maximize strontium decontamination, the models indicates one would keep each of the variables to their lowest levels tested. Conversely, to maximize plutonium decontamination, the opposite extremes of the levels of the tested variables are required with the exception of strontium addition. This dichotomy may help explain previous test results. Since reaching the required decontamination factor for strontium has not proven difficult in the peroxide tests report herein and the plutonium decontamination factors surpassed requirements, these data suggest that reagents levels of $0.005 \mathrm{M}$ strontium nitrate, $0.02 \mathrm{M}$ sodium permanganate, and $2 \mathrm{X}$ reductant (peroxide) concentration would accomplish the required radionuclide decontamination.

The data from the tests employing sodium formate as the reduction examined the same variables as the peroxide tests but also included mixing and temperature. Counter to the peroxide reduction results, the formate results mostly show agreement between the process parameter influence and the response ( $\mathrm{Sr}$ or $\mathrm{Pu} \mathrm{DF}$ ) except for temperature. For maximum decontamination, the strontium level should be low, reductant level should be high and the permanganate level high for Sr DF (not statistically significant for Pu DF). The two decontamination models, however, differ with respect to temperature. Since the range includes relatively low plutonium DF, a lower process temperature would aid in obtaining Pu DF and not adversely affect $\mathrm{Sr}$ DF. Therefore, process conditions would be $0.005 \mathrm{M} \mathrm{Sr}, 0.03 \mathrm{M} \mathrm{MnO}_{4}^{-}, 25$ ${ }^{\circ} \mathrm{C}$, reductant level at 3 times the permanganate level, and high level of mixing. 
For an In-Tank application of the sodium formate reduction process (see results in Table 10), the testing indicates that strontium nitrate addition influences only the Sr DF but permanganate addition affects $\mathrm{Sr}$ and $\mathrm{Pu} \mathrm{DF}$. Additionally, the maximum radionuclide decontamination occurs under opposite levels for Sr DF (Mn level low) and Pu DF (Mn level high). Under the high ionic strength of these test matrices, the dependence on reductant levels (concentration) is reduced. Lastly, for both radionuclides, the precipitation temperature should be maintained at the lower value $\left(25^{\circ} \mathrm{C}\right)$. The optima process and reagent level would be $0.005 \mathrm{M} \mathrm{Sr}, 0.03 \mathrm{M} \mathrm{Mn}$, reductant level at 1 times the permanganate level, and $25^{\circ} \mathrm{C}$.

In conclusion, the test results show several factors influence the degree to which the radionuclides are removed. However, with regards to the two premises that are proposed in this work (mixing and degree of excess of organic reductant), both conditions appear to be statistically significant. The higher the degree of mixing and the higher the excess of organic reductant studied in these tests, in general, the higher the decontamination factors.

\section{QUALITY ASSURANCE}

The following documents govern the work reported in this document.

- D. T. Hobbs, T. B. Peters, M. J. Barnes, M. C. Duff and K. M. Marshall, “Task Technical and Quality Assurance Plan for FY01 Strontium and Actinide Removal Testing," WSRC-RP2001-00188, Rev. 1, July 31, 2001.

- Savannah River Site Salt Processing Project: FY 2002 Research and Development Program Plan, PNNL-13707, Rev. 1, December 2001.

- Data is kept in notebook \# "WSRC-NB-2002-00141" titled "SRS Sr TRu”.

\section{ACKNOWLEDGEMENTS}

The authors appreciate H. D. Harmon (PNNL), P. C. Suggs (DOE-SR), and D. D. Walker for their assistance, support and insight. We thank B. H. Croy, M. S. Bloom, and H. L. Thacker for their assistance in the preparation of the permanganate samples. D. P. Diprete, C. C. Diprete, M. A. Malek, P. R. Woller and W. T. Boyce provided excellent analytical support and C. Pierce assisted us with the health physics aspects of this work. 
Wilmarth, et al.

WSRC-TR-2003-00413

Page 21 of 25

Approvals

Authors

W. R. Wilmarth, Waste Processing Technology

Date

J. T. Mills, Waste Processing Technology

Date

V. H. Dukes, Waste Processing Technology

Date

F. F. Fondeur, Waste Processing Technology

Date

D. T. Hobbs, Waste Processing Technology

Date

M. C. Duff, Waste Processing Technology

Date

Technical Reviewer

M. R. Poirier, Waste Processing Technology

Date

Management

S. D. Fink, Alpha Removal System Lead

Date

H. D. Harmon, Technology Development Manager

Date

R. H. Spires, Engineering Manager, Salt Processing Program

Date

W. D. Clark, Technical Support Manager, DOE

Date

J. C. Griffin, Waste Processing Technology

Date 
Page 22 of 25

Appendix 1. Simulated Waste Solution 5.6 M Na.

\begin{tabular}{|c|c|}
\hline Component & Solution Concentration (M) \\
\hline Free NaOH & 1.33 \\
\hline Total NaNO & 2.6 \\
\hline $\mathrm{NaAL}(\mathrm{OH})_{4}$ & 0.429 \\
\hline $\mathrm{NaNO}_{2}$ & 0.134 \\
\hline $\mathrm{Na}_{2} \mathrm{SO}_{4}$ & 0.521 \\
\hline $\mathrm{Na}_{2} \mathrm{CO}_{3}$ & 0.026 \\
\hline $\mathrm{U}^{238}$ & $4.2 \mathrm{E}-5$ \\
\hline $\mathrm{Pu}^{239}$ & $9.5 \mathrm{E}-7$ \\
\hline $\mathrm{Np}^{237}$ & $2.1 \mathrm{E}-6$ \\
\hline $\mathrm{Sr}^{85}$ & Tracer Amounts \\
\hline
\end{tabular}

Simulated Waste Solution 7.5 M Na

\begin{tabular}{|c|c|}
\hline Component & Solution Concentration (M) \\
\hline Free NaOH & 2.33 \\
\hline Total NaNO & 3.05 \\
\hline $\left.\mathrm{NaAL}_{3} \mathrm{OH}\right)_{4}$ & 0.429 \\
\hline $\mathrm{NaNO}_{2}$ & 0.584 \\
\hline $\mathrm{Na}_{2} \mathrm{SO}_{4}$ & 0.521 \\
\hline $\mathrm{Na}_{2} \mathrm{CO}_{3}$ & 0.026 \\
\hline $\mathrm{U}^{238}$ & $4.2 \mathrm{E}-5$ \\
\hline $\mathrm{Pu}^{239}$ & $9.5 \mathrm{E}-7$ \\
\hline $\mathrm{Np}^{237}$ & $2.1 \mathrm{E}-6$ \\
\hline $\mathrm{Sr}^{85}$ & Tracer Amounts \\
\hline
\end{tabular}


Page 23 of 25

Table 11. Data for 5.6 M Sodium Waste

\begin{tabular}{|c|c|c|c|c|c|c|c|c|c|c|}
\hline Test No. & $\mathrm{Sr}$ & $\mathrm{Mn}$ & Red Choice & Red Level & Mixing & Temp & $\begin{array}{c}\text { Pu-239 } \\
\text { (dpm/mL) }\end{array}$ & $\begin{array}{c}\text { Corrected } \mathrm{Pu} \\
\text { DF }\end{array}$ & $\begin{array}{c}\mathrm{Sr}-85 \\
(\mathrm{dpm} / \mathrm{mL})\end{array}$ & $\begin{array}{c}\text { Corrected Sr } \\
\text { DF }\end{array}$ \\
\hline 1 & 0 & 0.01 & Peroxide & $1 x$ & Stir bar & 25 & $3.04 \mathrm{E}+04$ & 1.1 & $3.20 \mathrm{E}+01$ & 4.E+03 \\
\hline 2 & 0.005 & 0.01 & Peroxide & $1 x$ & Stir bar & 25 & $5.26 \mathrm{E}+02$ & 61.1 & $3.19 \mathrm{E}+03$ & 39 \\
\hline 3 & 0.01 & 0.01 & Peroxide & $1 x$ & Stir bar & 25 & $7.17 \mathrm{E}+02$ & 44.8 & $1.93 E+03$ & 64 \\
\hline 4 & 0 & 0.01 & Peroxide & $3 x$ & Stir bar & 25 & $1.32 E+03$ & 24.4 & $4.90 \mathrm{E}+01$ & $2.54 \mathrm{E}+03$ \\
\hline 5 & 0.005 & 0.01 & Peroxide & $3 x$ & Stir bar & 25 & $1.70 \mathrm{E}+03$ & 18.9 & $1.80 \mathrm{E}+03$ & 69 \\
\hline 6 & 0.01 & 0.01 & Peroxide & $3 x$ & Stir bar & 25 & $1.63 E+03$ & 19.7 & $2.38 \mathrm{E}+03$ & 52 \\
\hline 7 & 0 & 0.03 & Peroxide & $1 x$ & Stir bar & 25 & $1.36 \mathrm{E}+04$ & 2.3 & $1.02 E+02$ & $1.20 \mathrm{E}+03$ \\
\hline 8 & 0.005 & 0.03 & Peroxide & $1 x$ & Stir bar & 25 & $1.99 E+04$ & 1.6 & $9.24 \mathrm{E}+01$ & $1.32 \mathrm{E}+03$ \\
\hline 9 & 0.01 & 0.03 & Peroxide & $1 x$ & Stir bar & 25 & $2.72 \mathrm{E}+04$ & 1.2 & $7.17 \mathrm{E}+01$ & $1.70 \mathrm{E}+03$ \\
\hline 10 & 0 & 0.03 & Peroxide & $3 x$ & Stir bar & 25 & $6.03 E+02$ & 52.4 & $8.39 \mathrm{E}+01$ & $1.45 \mathrm{E}+03$ \\
\hline 11 & 0.005 & 0.03 & Peroxide & $3 x$ & Stir bar & 25 & $6.16 \mathrm{E}+02$ & 51.2 & $6.98 \mathrm{E}+02$ & 175 \\
\hline 12 & 0.01 & 0.03 & Peroxide & $3 x$ & Stir bar & 25 & $3.31 E+02$ & 95.1 & $2.69 \mathrm{E}+03$ & 45 \\
\hline 13 & 0 & 0.03 & Formate & $1 x$ & Stir bar & 25 & $2.42 \mathrm{E}+03$ & 13.0 & 20.5 & $5.95 E+03$ \\
\hline 14 & 0 & 0.03 & Formate & $1 x$ & orbital & 25 & $6.97 E+03$ & 4.6 & 105 & $1.11 \mathrm{E}+04$ \\
\hline 15 & 0.01 & 0.03 & Formate & $1 x$ & Stir bar & 25 & $3.90 \mathrm{E}+03$ & 8.1 & $3.12 E+03$ & 39 \\
\hline 16 & 0 & 0.03 & Formate & $3 x$ & Stir bar & 25 & $1.90 \mathrm{E}+03$ & 16.6 & 19 & $6.40 \mathrm{E}+03$ \\
\hline 17 & 0 & 0.03 & Formate & $3 x$ & orbital & 25 & $4.16 \mathrm{E}+03$ & 7.7 & 6.685 & $1.74 \mathrm{E}+05$ \\
\hline 18 & 0.01 & 0.01 & Formate & $3 x$ & Stir bar & 25 & $3.87 E+03$ & 8.2 & $8.14 E+02$ & 150 \\
\hline 19 & 0.01 & 0.01 & Formate & $3 x$ & orbital & 25 & $7.45 E+03$ & 4.4 & $6.38 \mathrm{E}+04$ & 19 \\
\hline 20 & 0 & 0.03 & Formate & $1 x$ & Stir bar & 45 & $1.11 \mathrm{E}+04$ & 2.8 & $2.12 \mathrm{E}+01$ & 5756.66 \\
\hline 21 & 0.01 & 0.03 & Formate & $1 x$ & Stir bar & 45 & $8.72 E+03$ & 3.6 & $2.43 E+02$ & 501 \\
\hline 22 & 0 & 0.03 & Formate & $3 x$ & Stir bar & 45 & $9.05 E+03$ & 3.5 & 69.8 & 1.67E+04 \\
\hline 23 & 0.01 & 0.01 & Formate & $3 x$ & Stir bar & 45 & $1.05 E+04$ & 3.1 & 2.97E+03 & 398 \\
\hline
\end{tabular}


Page 24 of 25

Table 12. Data for 7.5 M Sodium Waste (Formate as Reductant)

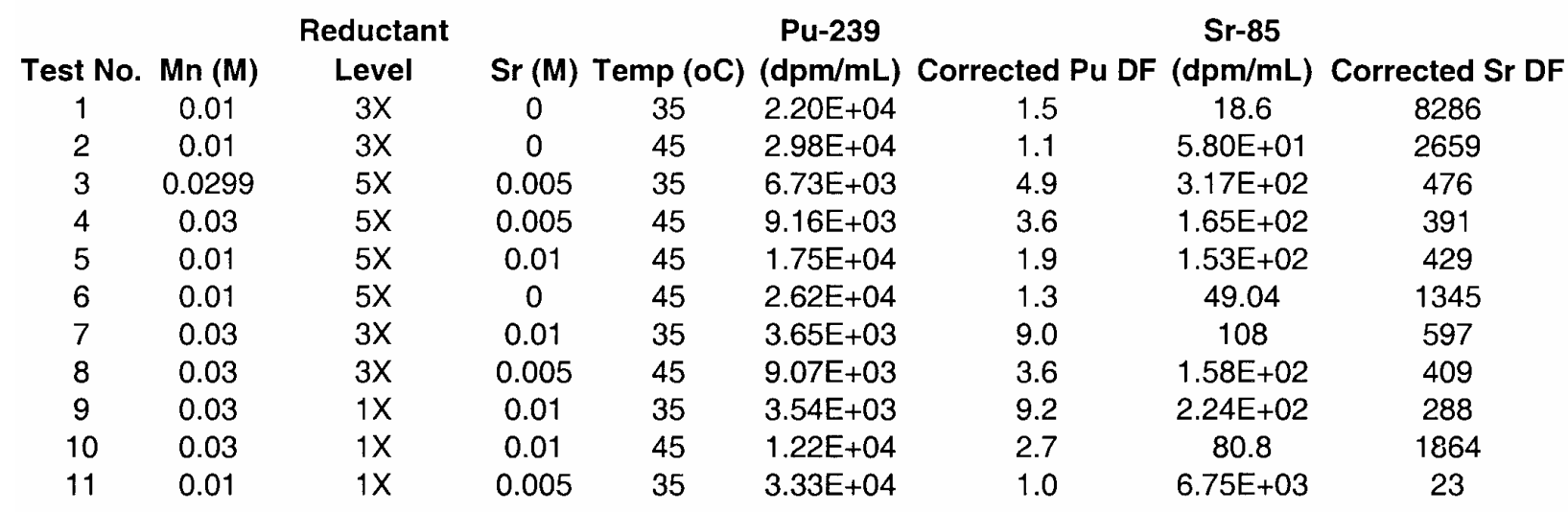




\section{References}

${ }^{1}$ D. T. Hobbs, "Evaluation of Alternative Materials and Methods for Strontium and Alpha Removal from Savannah River Site High-Level Waste Solutions," WSRC-TR-2000-00229, August 2000.

${ }^{2}$ R. A. Dimenna, et al., "Bases, Assumptions, and Results of the Flowsheet Calculations for the Decision Phase Salt Disposition Alternatives," WSRC-RP-99-00006, Rev. 3.

${ }^{3}$ W. R. Wilmarth, S. W. Rosencrance, C. A. Nash, D. P. DiPrete and C. C. DiPrete,

"Transuranium removal from Hanford High Level Waste simulants using sodium permanganate and calcium," J. Radioanal. Nucl. Chem., 247, 2001, p. 501.

${ }^{4}$ M. J. Barnes, D. T. Hobbs, M. C. Duff and S. D. Fink, "Strontium and Actinide Removal from Savannah River Site Actual Waste Samples by Freshly Precipitated Manganese Oxide," WSRCTR-2002-00048, Rev. 1, May 22, 2002.

${ }^{5}$ M. C. Duff, D. T. Hobbs and S. D. Fink, "Permanganate Treatment Optimization Studies for Strontium and Actinide Removal from High Level Waste Simulants," WSRC-TR-2002-00027, Rev. 0, January 14, 2002.

${ }^{6}$ N. N., Krot, A. A. Bessonov, A. V. Gelis, V. P. Shilov, V. P., Perminov. and L. N. Astafurova,. Coprecipitation of transuranium elements from alkaline solution by the method of appearing agents. I. Coprecipitation of $\mathrm{Pu}(\mathrm{VI}, \mathrm{V})$ with manganese dioxide. Radiochem. 40, 1998, 347-352.

${ }^{7}$ D. T. Hobbs, "Recommended Decontamination Factors for Use in Flowsheet Modeling of the Manganese Oxide Treatment Process for Strontium and Actinide Removal," WSRC-TR-200200379, August 20, 2002.

${ }^{8}$ D. T. Herman, M. R. Poirier, D. T. Hobbs and S. D. Fink, "Testing of a Rotary Microfilter using SRS Actual Waste," WSRC-MS-2003-00030, February 2003.

${ }^{9}$ Statistical Consulting Section, "Software Verification and Validation for Commercial Statistical Packages Utilized by the Statistical Consulting Section of SRTC," WSRC-RP-9900422, Rev. 0, May 21, 1999. 